\title{
Presidential Speech
}

\author{
B. M. Daver \\ Consultant Plastic Surgeon, Mumbai, India
}

Delivered at the $9^{\text {th }}$ Congress of The Asian Pacific Section of IPRAS held from 19th to 23rd March 2005 in Mumbai India

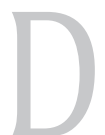

r. Hoehn, Secretary General of the International Confederation of Plastic, Reconstructive and Aesthetic Surgery, Dr. Yu-Ray Chen, General Secretary of the Asian Pacific Section, faculty members, delegates and friends.

It is indeed an honour and a privilege to host the $9^{\text {th }}$ Asian Pacific Congress in Mumbai. This meeting, which is held every four years, is the most awaited scientific event for plastic surgeons in the Asian Pacific region and I am indeed very happy that so many of you have come to Mumbai to attend the meeting. And to ensure that this meeting is truly International, we have invited a number of eminent plastic surgeons from all over the world to actively participate in the scientific deliberations.

As President of the $9^{\text {th }}$ Asian-Pacific Congress it gives me great pleasure to welcome you all to this City of Gold, and may I assure you that a veritable treat has been organised by the Scientific Committee.

Over the last 2000 years, ever since Sushruta reconstructed the nose with cheek flaps, plastic surgery has evolved into a powerful force, an art, a science and a profession that has made a quantum leap into the $21^{\text {st }}$ Century.

However, this progress has led to problems that we need to face and solve. The two most obvious developments that we need to come to grips with are overspecialization and the emphasis on cosmetic surgery. Today, the lay public believes that Plastic Surgery is synonymous with Cosmetic Surgery and most of the younger plastic surgeons want to concentrate on this branch of plastic surgery. This trend is not restricted to the Asian-Pacific Region; it is infact a worldwide phenomenon and needs to be recognised and addressed by us.

Another problem, if it can be called that, is the encroachment of other specialties into what was till recently considered our domain. What can and should be done by Plastic Surgeons is a question, which has become irrelevant. The answer lies in doing it better and keeping up with the latest ideas and trends. And it is precisely for this reason that Conferences like this one are of such great importance. Exchange of ideas and sharing of experiences are of paramount importance, but what is equally important is asking questions. Gertrude Stein is said to have asked on her deathbed "What is the answer?" Getting no reply she said "In that case, what is the question?" And if no questions are asked nothing new would ever be learned.

Today, the world is getting smaller and a procedure developed in one part of the world is quickly duplicated in another. Congresses like this one are chiefly responsible for this healthy trend and need to be encouraged. However, technical expertise is not enough. Integrity, compassion and altruism are the need of the day and need to be inculcated in our budding plastic surgeons. Ethics, unfortunately, is often forgotten and if remembered is given little importance. This is indeed sad because right from antiquity, from the time of Imotep in Egypt, Hippocrates in Greece, and Charaka and Sushruta in India, medicine is associated with certain ethical norms, the important ones being empathy with the patient, care and compassion, and the patients wellbeing. And they are as pertinent to our specialty today as to medicine in 
general.

May I also stress that the medical profession is quite different from other professions. It is truly an altruistic profession and it is the duty of all well-meaning plastic surgeons to rise above the common herd and put it in practice.

I would like to conclude by addressing our young plastic surgeons present in this room today with a few lines from a poem by Rudyard Kipling, whose father was a resident of this city and responsible for many of the beautiful sculptures atop our Victorian buildings:

"If you can keep your head when all about you are losing theirs and blaming it on you;

If you can trust yourself when all men doubt you, but make allowance for their doubting too,

If you can dream, and not make dreams your master, If you can think, and not make thoughts your aim, If you can meet Triumph and Disaster and treat those two imposters just the same;

Yours is the Earth and everything that's in it."

Ladies and Gentlemen, thank you for your patient hearing.

\title{
Annoucement
}

The 40th Annual Conference of the Association of Plastic Surgeons of India to be held at India Habitat Centre, New Delhi, from 6th - 10th November, 2005.

A pre-conference workshop on "Surgery of the Breast" has been planned for 6th November, 2005 at Research \& Referral Hospital (Army Hospital), Delhi Cantt.-110010.

\author{
For details contact \\ APSICON 2005 \\ Conference secretariat \\ Department of Burns \& Plastic Surgery, \\ Ward 21, Lok Nayak Hospital, \\ Jawahar Lal Nehru Marg, \\ New Delhi - 110002 \\ $\mathrm{Ph}:+911123231871$ \\ Fax : + 911123222756 \\ Website : www.apsicon2005.org \\ secretariat@apsicon2005.org
}

